\title{
Psychopharmacological effects of riparin III from Aniba riparia (Nees) Mez. (Lauraceae) supported by metabolic approach and multivariate data analysis
}

Sócrates Golzio dos Santos', Isis Fernandes Gomes ${ }^{1}$, Adriana Maria Fernandes de Oliveira Golzio², Augusto Lopes Souto', Marcus Tullius Scotti ${ }^{1}$, Josean Fechine Tavares' ${ }^{1}$, Stanley Juan Chavez Gutierrez' Reinaldo Nóbrega de Almeida', José Maria Barbosa-Filho ${ }^{1}$ and Marcelo Sobral da Silva ${ }^{1 *}$ (i)

\begin{abstract}
Background: Currently there is a high prevalence of humor disorders such as anxiety and depression throughout the world, especially concerning advanced age patients. Aniba riparia (Nees) Mez. (Lauraceae), popular known as "louro", can be found from the Amazon through Guianas until the Andes. Previous studies have already reported the isolation of alkamide-type alkaloids such as riparin III (O-methyl-N-2,6-dyhydroxy-benzoyl tyramine) which has demonstrated anxiolytic and antidepressant-like effects in high doses by intraperitoneal administration.

Methods: Experimental protocol was conducted in order to analyze the anxiolytic-like effect of riparin III at lower doses by intravenous administration to Wistar rats (Rattus norvegicus) $(n=5)$. The experimental approach was designed to last 15 days, divided in 3 distinct periods of five days: control, anxiogenic and treatment periods. The anxiolytic-like effect was evaluated by experimental behavior tests such as open field and elevated plus-maze test, combined with urine metabolic footprint analysis. The urine was collected daily and analyzed by ${ }^{1} \mathrm{H}$ NMR. Generated data were statistically treated by Principal Component Analysis in order to detect patterns among the distinct periods evaluated as well as biomarkers responsible for its distinction.

Results: It was observed on treatment group that cortisol, biomarker related to physiological stress was reduced, indicating anxiolytic-like effect of riparin III, probably through activation of 5- $\mathrm{HT}_{2 \mathrm{~A}}$ receptors, which was corroborated by behavioral tests.
\end{abstract}

Conclusion: ${ }^{1} \mathrm{H}$ NMR urine metabolic footprint combined with multivariate data analysis have demonstrated to be an important diagnostic tool to prove the anxiolytic-like effect of riparin III in a more efficient and pragmatic way.

Keywords: Metabolomics analysis, Footprint, Urine, Aniba riparia, Riparin, Anxiety animal model

\footnotetext{
* Correspondence: marcelosobral.ufpb@gmail.com

'Instituto de Pesquisa de Fármacos e Medicamentos - IPeFarM, Universidade

Federal da Paraíba, João Pessoa, PB 58051-900, Brazil

Full list of author information is available at the end of the article
}

C C The Author(s). 2020 Open Access This article is licensed under a Creative Commons Attribution 4.0 International License, which permits use, sharing, adaptation, distribution and reproduction in any medium or format, as long as you give appropriate credit to the original author(s) and the source, provide a link to the Creative Commons licence, and indicate if changes were made. The images or other third party material in this article are included in the article's Creative Commons licence, unless indicated otherwise in a credit line to the material. If material is not included in the article's Creative Commons licence and your intended use is not permitted by statutory regulation or exceeds the permitted use, you will need to obtain permission directly from the copyright holder. To view a copy of this licence, visit http://creativecommons.org/licenses/by/4.0/. The Creative Commons Public Domain Dedication waiver (http://creativecommons.org/publicdomain/zero/1.0/) applies to the data made available in this article, unless otherwise stated in a credit line to the data. 


\section{Background}

Currently there is a high prevalence of humor disorders, such as anxiety and depression [1, 2]; concerning advanced age patients, these psychiatric disorders are considered even more prevalent [3]. Many factors are involved in the etiology of anxiety, including genetics, gender, brain chemistry and incontrollable stressful events [4]. Previous research have demonstrated that medicinal plants have anxiolyticlike activity [5-10] and have been successfully used by folk medicine [11]. Aniba riparia (Nees) Mez. (Lauraceae) is a popular plant well known as "louro", found from the Amazon and Guianas until the Andes, rich in Alkamide-type alkaloids, which were isolated from the green fruit of this species, such as riparin III (O-methyl-N-2,6-dyhydroxybenzoyl tyramine) [12-14]. Previous in vivo studies have demonstrated anxiolytic and antidepressant-like effects of riparin III in high doses by intraperitoneal and oral administration [15]. Moreover, alkamides with similar chemical structures, such as riparin I and II have already demonstrated antinociceptive [16, 17] anxiolytic [18] and antidepressant-like effects [19]. Besides, semisynthetic chemicals (riparin A) have also proved its anxiolytic-like effects [20], supporting the important pharmacological activity of riparin and its variations.

Metabolomics is the science that studies the endogenous metabolites as a reflection of pathophysiological processes [21-24]. These metabolites play an important role as biomarkers, once its dynamic balance at biological fluids and tissues indicates a homeostasis state [25, 26]. In this context, abnormal metabolite processes or alterations in the metabolic balance caused by exogenous products characterize a certain profile that can be analyzed by techniques such as nuclear magnetic resonance (NMR) and mass spectrometry (MS) [21]. NMR is a technique that provides qualitative and quantitative measures of several compounds contained in a complex matrix [27]; unlike MS, NMR does not require complex pre-treatment of samples. Recently, numerous techniques have been developed in order to characterize metabolites and biological fluids [28]. The data obtained from these techniques treated with a chemometric approach can be used for clinical applications or as diagnostic tools [29], therefore, metabolomics platform associated with principal component analysis (PCA) [30] has demonstrated to be a very useful method in order to interpret multivariate data generated from the analyses of biological matrixes such as urine [31-33]. No bioanalytical method regarding determination of metabolic profile of anxious and stressed rats has been previously reported in the literature, as well as the detection of biomarkers correlated to riparin III administration at lower doses. Therefore, this present study has demonstrated the psychopharmacological effect of riparin III, through metabolic profiling of rats urine samples, performed by ${ }^{1} \mathrm{H}$ NMR combined with multivariate data analysis.

\section{Methods}

\section{Chemicals and reagents}

Riparin III was obtained by organic synthesis and donated from Dr. Stanley Juan Chavez Gutierrez, and Dr. José Maria Barbosa Filho from Universidade Federal da Paraíba, Brazil, according to methodology previously described in literature [34].

During the whole experiment it was used ultra-pure water (Type I) obtained by Option-Q Purelab labwatersystem (Elga, São Paulo, Brasil), deuterated water with sodium salt of 3-(trimethylsilil) propionic acid- $\mathrm{d}_{4}$ (TSP, $0.1 \%[\mathrm{w} / \mathrm{v}]$ in $\mathrm{D}_{2} \mathrm{O}$ ) (Sigma-Aldrich, Brasil). Phosphate buffer (0.2 $\mathrm{M} \mathrm{Na}_{2} \mathrm{HPO}_{4} / \mathrm{NaH}_{2} \mathrm{PO}_{4}, \mathrm{pH}$ 7.4).

\section{Standard solutions preparation}

Riparin III was diluted in ultra-pure water with $0.1 \%$ of cremophor EL (Sigma-Aldrich, Brazil) in order to obtain an equivalent solution to a $5 \mathrm{mg} \cdot \mathrm{kg}^{-1}$ dose, which was injected in each rat the correspondent value in volume of the solution.

Riparin III was also diluted with $50 \mu \mathrm{L}$ of acetonitrile, HPLC grade (Tedia, Brazil), and phosphate buffer $0.2 \mathrm{M}$ in order to obtain a final solution of $1 \mathrm{mg} \cdot \mathrm{mL}^{-1}$ as NMR reference standard using the PRESAT method and TOCSY. Another sample of riparin III was also diluted with $50 \mu \mathrm{L}$ of acetonitrile and rat urine in order to obtain a solution of $1 \mathrm{mg} \cdot \mathrm{mL}^{-1}$ as NMR reference standard which was also evaluated by the PRESAT method and TOCSY, this same procedure was repeated using water instead of urine for further observation of chemical shifts.

\section{Animals}

The wistar rats (Rattus norvegicus), weighing approximately 250 g, 90 days old, were obtained from the Prof. Dr. Thomas George bioterium and maintained on standard laboratorial conditions: controlled temperature (21 \pm $1{ }^{\circ} \mathrm{C}$ ), $12 \mathrm{~h}$ light-dark cycle (lights on from 07:00 AM to

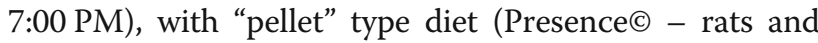
mice, Brazil) and water ad libitum. The whole experiment was approved by the ethics committee in animal research (ECAR) under protocol $n^{\circ}$ 0107/08, from the Universidade Federal da Paraíba, João Pessoa/Paraíba, Brazil. The protocols are in agreement with the guidelines of the National Institute of Health (NIH Publication, Health Research Extension Act of 1985 Public Law 99-158, November 20, 1985 "Animals in Research") regarding animal care in laboratory.

\section{Experimental protocol}

Firstly, the experimental protocol was performed with five Wistar rats, which were set in metabolic cages for 3 days [35], individually housed and maintained on standard laboratorial conditions. After 3 days, the animals remained for 5 days in its cages with the same conditions, with urine 
collection in every $24 \mathrm{~h}$, for further analysis; this period was termed as control period (CP). The method was adapted from Aikey, Nyby [36], Broadhurst [37] and Broadhurst [38]. After the control period (CP), on the 5th day, the animals were submitted to the open field (OF) and elevated plus-maze tests (EPM), followed by the anxiogenic period (AP), which lasted 5 more days. The animals of AP went through food restriction in alternate days $(24 \mathrm{~h}$ with food, followed by $24 \mathrm{~h}$ without food) $[39,40]$. During this period, the animals were also placed collectively in the open field instrument and were submitted in a certain period of the day (10:30 a.m. - 03:00 GMT) to a sequence of sounds, from $5 \mathrm{~Hz}$ to $90 \mathrm{kHz}$, with an intensity of $80 \mathrm{~dB}$, for $10 \mathrm{~min}$ $[41,42]$, these same procedure was repeated in the afternoon (4:30 p.m. - 03:00 GMT). The animals also went through forced swimming in plastic container $(37 \mathrm{~cm}$ of diameter and $42.5 \mathrm{~cm}$ of height, containing $30 \mathrm{~cm}$ of water a $25 \pm 2{ }^{\circ} \mathrm{C}$ ), individually, once a day, for $3 \mathrm{~min}$. After each test, the animals were retrieved, dried and returned to its respective cages [43], the execution of the procedure was conducted twice a day, during the morning (10:30 a.m. 03:00 GMT) and afternoon (4:30 p.m. - 03:00 GMT). On the 5th day of AP, the animals went through open field and elevated plus-maze tests. Posteriorly the animals were submitted to a period termed as treatment period (TP), for five more days, where they went through the same manipulation of AP, with an additional intravenous administration of riparin III, every day at 10:15 a.m. Finally, on the 5th day of TP, the animals were also submitted to open field and elevated plus-maze tests. After these experiments, the animals were anesthetized with ketamine hydrochloride $(150 \mathrm{mg} / \mathrm{kg})$, by intramuscular administration and xylazine hydrochloride $(11 \mathrm{mg} / \mathrm{kg})$ by intraperitoneal administration in order to eliminate the corneal reflex [44], after verification of the absence of this reflex, the animals suffered euthanasia by potassium chloride administration $(2 \mathrm{mmol} / \mathrm{Kg})$ followed by cervical dislocation [45]. Experimental design concerning animal manipulation and sample collection is demonstrated in Fig. 1.

\section{Behavioral tests \\ Elevated plus-maze test}

The elevated plus-maze test (EPM) was conducted with a plus-shaped apparatus $(10 \times 10 \mathrm{~cm})$, made of acrylic, with two open $(50 \times 10 \times 0.5 \mathrm{~cm})$ and two enclosed arms $(50 \times$ $10 \times 42 \mathrm{~cm})$, slightly elevated $(54,5 \mathrm{~cm})$, specifically designed to study behavioral changes predominantly associated with anxiety [46], once general behavior of rodents related to anxiety is the avoidance of open and elevated spaces [47, 48]. For behavioral evaluation, rodent was placed at the central platform facing the open arm, to manually measure the number of entries in the open and closed arms, as well as the time of permanence in both open arms, during the 5 min test [49]. The entry to one arm was only scored when the four paws of the animal were fully inside. During the 5 min test the behavior of rodent was recorded by video camera (SONY, model DSC-W180).

\section{Open field test}

The open field test (OF) was performed with a specific apparatus from Insight Equipamentos Científicos, model EP 154, made with acrylic, white floor with $70 \mathrm{~cm}^{2}$ area, delimited by black stripes in order to keep animal locomotion score. The field is constituted of two concentric

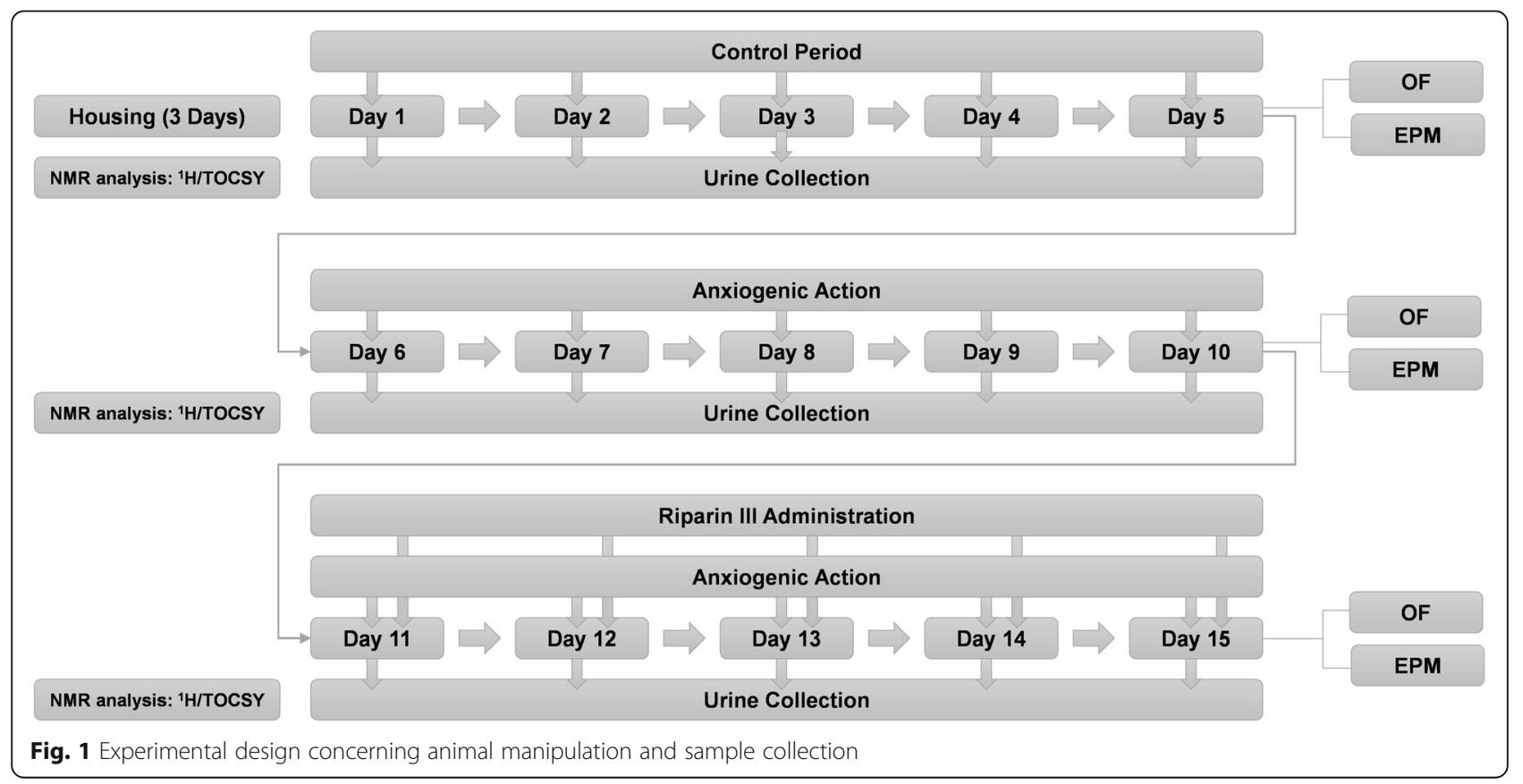


circles, one circle with $30 \mathrm{~cm}$ of diameter and the other with $60 \mathrm{~cm}$, in which the latter is delimited by a transparent cylinder of $50 \mathrm{~cm}$ (height) $\times 60 \mathrm{~cm}$ (diameter) with an illumination level of $2251 \mathrm{x}$. The behavior was scored according to definitions previously stablished [50]: the data were registered according to the number of ambulations (number of squares explored by each mouse with the four limbs), grooming, rearing and defecation. During the 5 min test, the animal behavior was recorded by video camera (SONY, model DSC-W180).

\section{Urine collection}

This experiment was conducted for 15 days (excluding the first 3 days), all animals were weighed, the ration was measured during feeding days for consumption observation, volume of consumed water was also measured every $24 \mathrm{~h}$, as well as the urinary volume and its $\mathrm{pH}$, monitored with Merck tape. Aliquots of $300 \mu \mathrm{L}$ of urine from each rodent were sampled for instant analysis every $24 \mathrm{~h}$.

\section{Measure of urine samples by ${ }^{1} \mathrm{H}$ NMR spectroscopy}

To each aliquot $(300 \mu \mathrm{L})$ of urine, from each animal, $300 \mu \mathrm{L}$ of phosphate buffer were added $\left(0,2 \mathrm{M} \mathrm{Na}_{2} \mathrm{HPO}_{4} /\right.$ $\mathrm{NaH}_{2} \mathrm{PO}_{4}, \mathrm{pH}$ 7.4) in order to minimize chemical shift variation. After mixing, the sample was homogenized in vortex for $30 \mathrm{~s}$, followed by centrifugation at $14000 \mathrm{x} g$, during 10 $\min$, at $15^{\circ} \mathrm{C}$. The supernatant $(500 \mu \mathrm{L})$ was retrieved and mixed with $60 \mu \mathrm{L}$ of $\mathrm{D}_{2} \mathrm{O}$ with TSP $0.1 \%$ [w/v], for "locking" field frequency and the sodium salt of 3-(trimethylsilil) propionic acid-d4 (TSP, $0.1 \%[\mathrm{w} / \mathrm{v}]$ em $\mathrm{D}_{2} \mathrm{O}$ ) was used as internal standard, as chemical shift $(\delta 0)$ reference. The aliquots were transferred to $7 \mathrm{~mm}$ NMR tubes [51], and all the spectra were determined by a 500 $\mathrm{mHz}$ spectrometer from Varian, operating at $30^{\circ} \mathrm{C}$ and spin frequency of $20 \mathrm{~Hz}$. Unidimensional spectra were acquired by the PRESAT methodology with the following parameters: spectral window $8012.8 \mathrm{~Hz}, 32 \mathrm{~K}$ complex data points, 64 transients, acquisition time $2.3 \mathrm{~s}$, relaxation time $2.0 \mathrm{~s}$, pulse observation $4.56 \mu \mathrm{s}$ with a $45^{\circ}$ angle, line-broadening of $0.5 \mathrm{~Hz}$. Additional conditions such as saturation time at $1.5 \mathrm{~s}$ and saturation power at $10 \mathrm{~dB}$ were stablished to suppress the water signal $[52,53]$. Confirmation of the metabolites structure was achieved by bidimensional spectra acquired with TOCSY methodology following the parameters: spectral window $8012.8 \mathrm{~Hz}, 32 \mathrm{~K}$ complex data points, 8 transients, acquisition time $2.3 \mathrm{~s}$, relaxation time $2.0 \mathrm{~s}$, pulse observation $4.56 \mu \mathrm{s}$ with a $45^{\circ}$ angle, line-broadening of $0.5 \mathrm{~Hz}$ and additional conditions such as saturation time of $1.5 \mathrm{~s}$ and presaturation of the water peak with saturation power at $10 \mathrm{~dB}$ for suppression. Confirmation of the substances were also done by literature research.

\section{Statistical analysis}

Statistical analysis of ${ }^{1} \mathrm{H}$ NMR spectra from urine samples

Spectral intensities (peaks) were integrated into regions or binnings of equal width $(0.02 \mathrm{ppm})$ comprising the range from 0.005 to $10 \mathrm{ppm}$. Spectral regions, corresponding to residual water $(\delta 4.75)$ were suppressed from all samples, in order to avoid efficiency variation of the process. Spectra were referenced to TSP as internal standard [53]. The ${ }^{1} \mathrm{H}$ NMR spectroscopic data were reduced into 496 integral segments of equal length $(0.02 \mathrm{ppm})$ and were exported into ASCII format to produce a data matrix of sample versus integral segments. Integrated areas were normalized to equal the total area and were submitted to Principal Component Analysis, using "The Unscrambler", version 9.7 as statistical software (CAMO Process AS, Norway).

\section{Statistical analyses of anxiety parameters from open field test, elevated plus-maze test, physiologic parameters and metabolic peaks}

The data obtained were evaluated with one-way ANOVA followed by Bonferroni post hoc test, results with $p$ values $<0.05$ were considered statistically significant.

\section{Results}

The elevated plus-maze is a validated test designed to evaluate the effects of anxiolytic drugs, once rodents have natural fear of heights and open spaces, therefore, in this particular test, the fact that the animal avoids open arms, characterize an anxiety-like behavior [47, 54].

The results have demonstrated that there was no significant difference among $\mathrm{CP}, \mathrm{AP}$ and TP groups, considering the number of entries on open arms. The same was observed concerning closed arms entries. However, the number of entries on closed arms by all tested groups were significantly higher than the number of entries on open arms by its respective groups (Fig. 2a).

Regarding the remaining time of the animals on open and closed arms, there was no significant change among groups. However, CP, AP and TP groups have remained more time on closed arms than its respective groups on open arms (Fig. 2b).

Therefore, the TP group, treated with Riparin III did not present a decrease regarding the number of entries or remaining time on closed arms when compared to $\mathrm{CP}$ and $\mathrm{AP}$ groups, indicating an anxiolytic-like effect.

Comparing altogether (number of entrances to open arms, closed arms and remaining periods), it could be observed that there was no alteration in associative memory and processing [55]. The use of drugs with hypnotic or sedative activity also diminishes mobility [56], in this context, treatments that block conditional fear may not necessarily block anxiety [57]. Therefore, stress would be defined as a threat to the homeostasis, which 

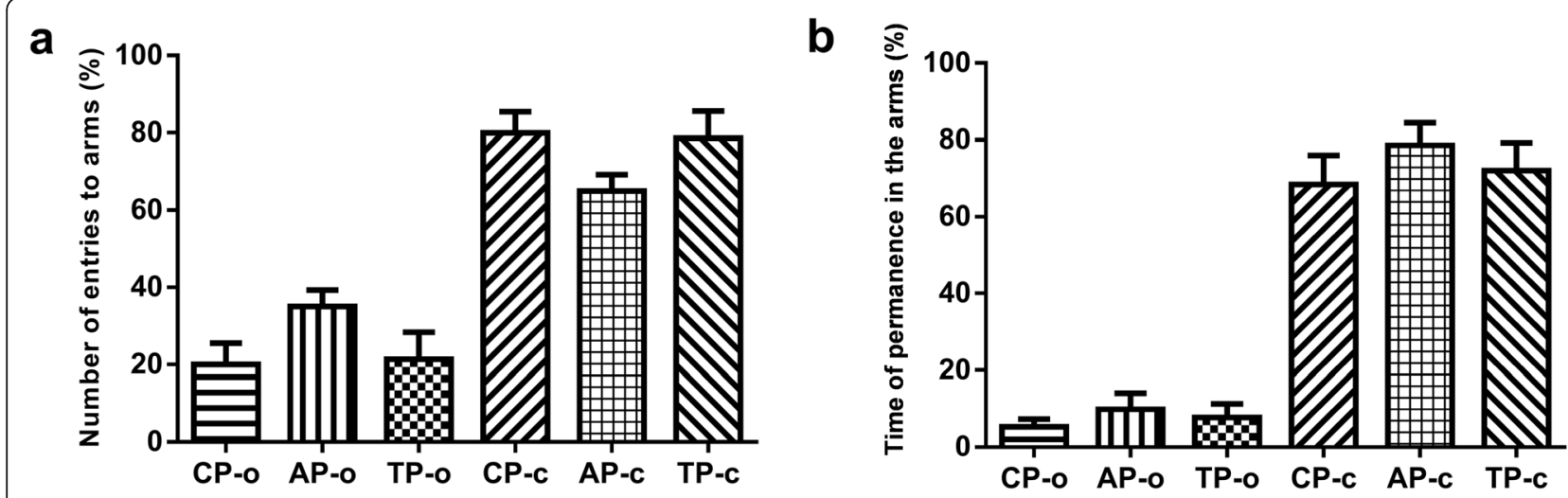

Fig. 2 Elevated Plus-maze test. Numbers of entries to arms (a). Time of permanence on the open and closed arms (b). CP-o: Control Period (open arms). CP-c: Control Period (closed arms).AP-o: Anxiogenic Period (open arms). AP-c: Anxiogenic Period (closed arms). TP-o: Treatment Period (open arms). TP-c: Treatment Period (closed arms)

may be restored by a complex repertoire of physiological and behavioral responses concerning its adaptation [58].

The open field test is used to evaluate the locomotor activity of the animal as an essential parameter to analyze the drug effect towards central nervous system (CNS). On this specific test, the animal is submitted to a new environment, promoting a tendency to be explored, evoking fear and curiosity, being considered a behavioral model [59]. The principle of this test is based on the increasing number of ambulations and rearings frequencies, characterizing an

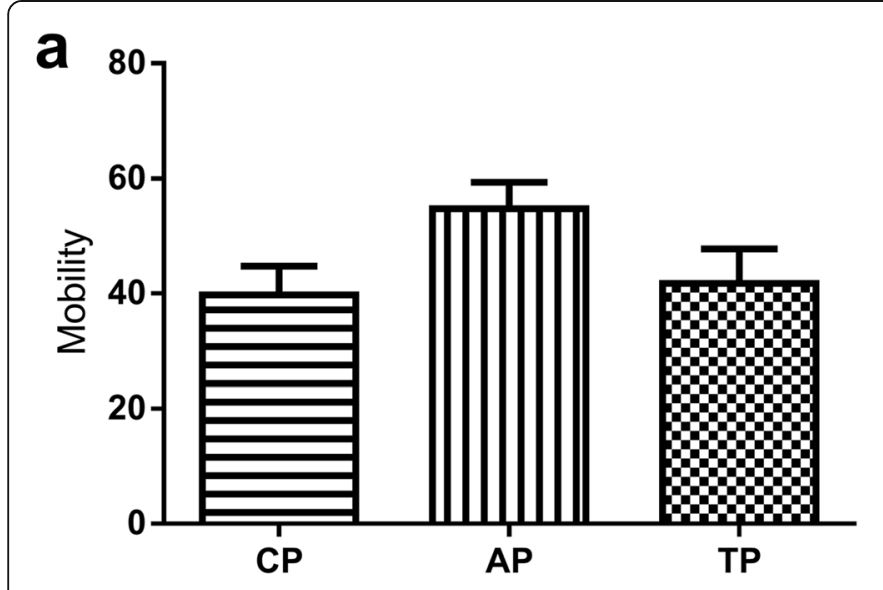

b
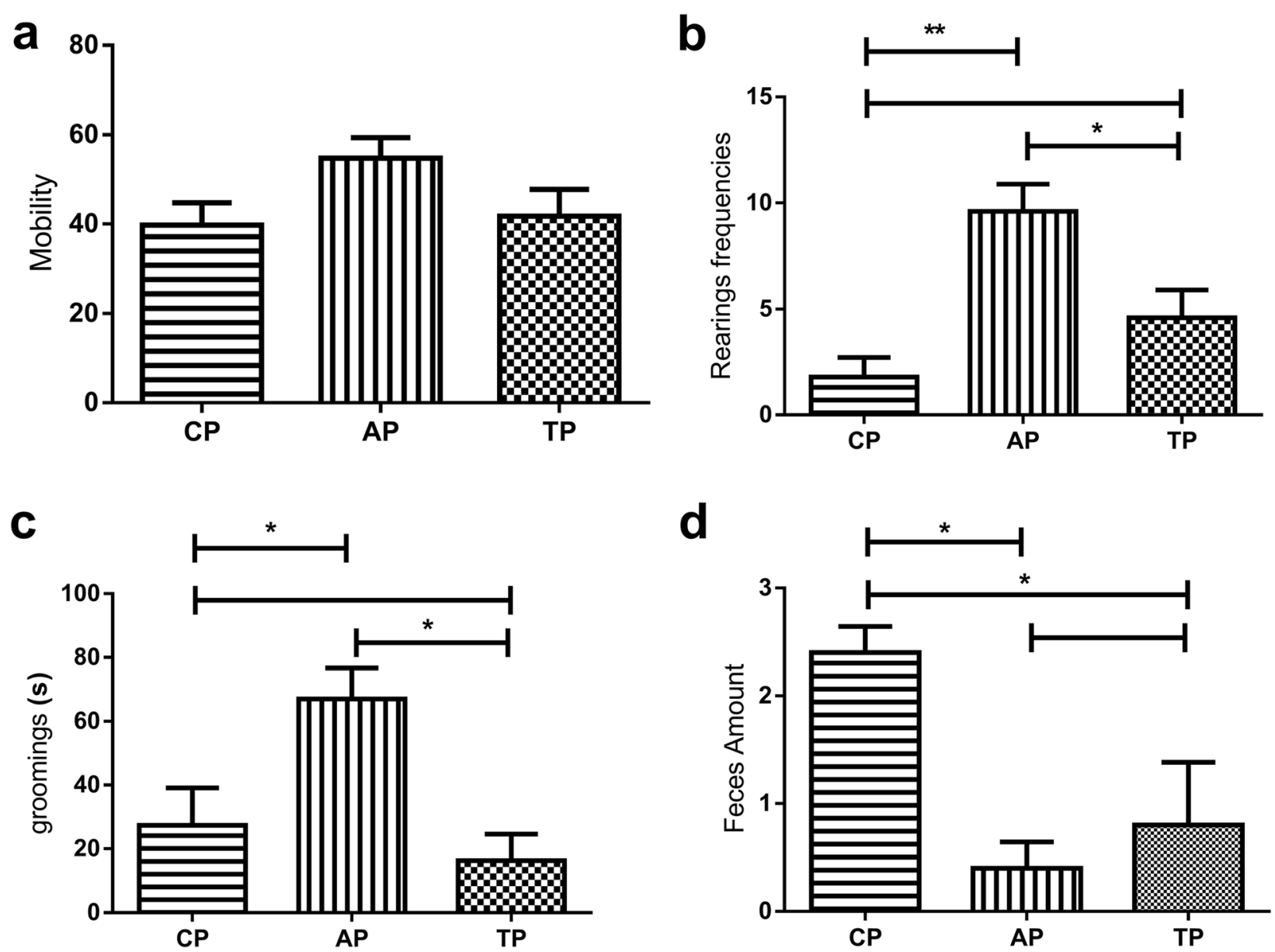

Fig. 3 Open Field test. Mobility (a). rearings (b). groomings (c). feces amount (d). CP: Control Period. AP: Anxiogenic Period. TP: Treatment Period 
anxiolytic-like behavior, while the reduction of locomotion stands for sedative effect [60].

There was also observed no alteration of fear, when mobility was evaluated, showing no significant differences among periods (CP, AP and TP) (Fig. 3a), demonstrating that at this dose the drug has no hypnotic or sedative effect, as well as fear inhibition [61]. On Fig. 3b, it was observed that the treatment with riparin III (TP) has diminished significantly the rearing frequencies of the animals, when compared to AP, and has not presented significant difference when correlated with $\mathrm{CP}$, suggesting that the drug at this dose caused alteration on alert behavior [62]. This same observation was corroborated by evaluation of grooming (Fig. 3c), which has decreased significantly when comparing TP to AP. Moreover, TP did not present significant alteration when related to $\mathrm{CP}$, demonstrating anxiolytic-like effect of the drug [63]. Number of defecations (Fig. 3d) has decreased significantly when comparing $\mathrm{CP}$ to AP and TP, besides, no significant difference was observed between AP and $\mathrm{TP}$, demonstrating that the anxiogenic facts have altered the animals emotionally [64, 65], leading only to activity decrease [66].

Concerning behavioral evaluation, it was observed that the anxiogenic factors have stressed the animals during the whole experiment, preserving the vigilant state and leading the animals to escape and seek for safe places [63], typical defensive reactions related to anxiety [67].

On Fig. 4a, concerning feeding, as physiological parameter, measured by ration consumption, there was observed significant difference between CP and AP $(p<$ $0.0001)$, as well as, between CP and TP $(p<0.05)$, but no significant difference between AP and TP.

The difference related to $\mathrm{CP}$ is due to the null values, registered during feeding restriction time of $24 \mathrm{~h}$, nevertheless, it was not observed the riparin III effect regarding hanger/ feeding parameter [68], when comparing AP to TP.

On Fig. 4b, regarding weight, as physiological parameter, there was observed a significant difference between CP and AP $(p<0,0001)$, as well as, between CP and TP $(p<0.0001)$, but no significant difference between AP and TP; these differences presented, do not reflect

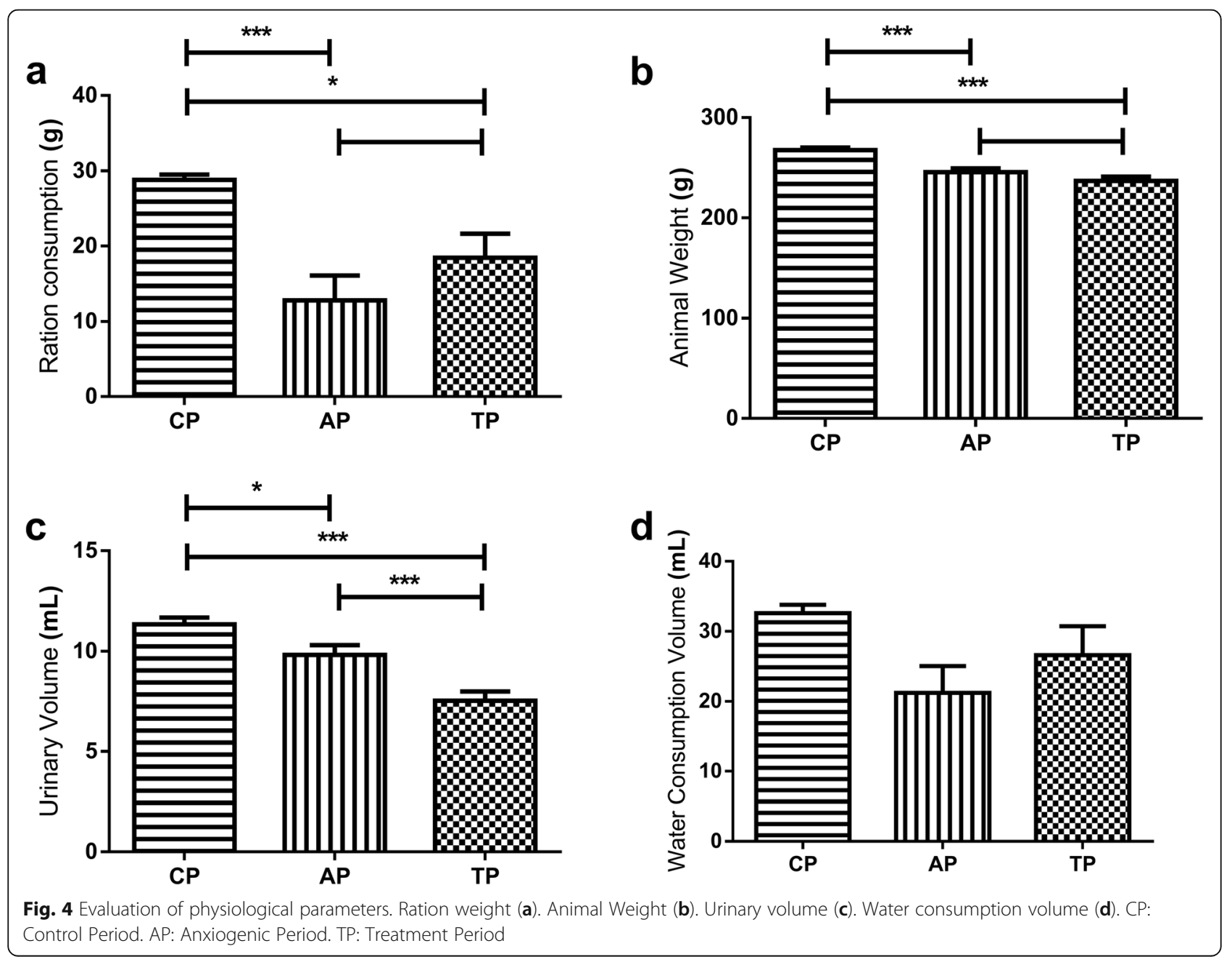


directly on the anxiogenic factors or the riparin III towards the $\mathrm{CP}$ due to fee restriction of $24 \mathrm{~h}$, suggesting the influence of innutrition towards substantial weight loss [69-72].

On Fig. 4c, regarding urinary volume, it was detected a significant difference between $\mathrm{CP}$ and AP $(p<0.05), \mathrm{CP}$ and TP $(p<0.0001)$, as well as between AP and TP $(p<$ 0.0001). These data have demonstrated that during anxiogenic period, physiological alterations decreased the average urinary volume eliminated by the animals, corroborating with the data of Ullrich, Lutgendorf [73]. The use of riparin III $\left(5 \mathrm{mg} \cdot \mathrm{kg}^{-1}\right)$ has reduced the average urinary volume [74]. Regarding bladder functions, considering that the micturition reflex is controlled by inhibitory mechanisms, and that the storage urine function is more important than micturition reflex by evolutionary reasons [75], the serotoninergic system may be involved at blocking mechanisms over afferent nerve of micturition reflex and urethra contraction, probably through glycinergic neurone inhibition, from lumbosacral marrow. Furthermore, the $5-\mathrm{HT}_{2 \mathrm{~A}}$ receptors may be involved on bladder and urethra functions as well. The results suggest that riparin III has effect over the 5$\mathrm{HT}_{2 \mathrm{~A}}$ receptors from amygdala [76], once this drug has demonstrated its anxiolytic-like effect on open field tests, by decreasing activity parameters, such as grooming and rearing (Fig. 3 B e D) [77]; however, it has presented no effect over reward system which has the $5-\mathrm{HT}_{1 \mathrm{~B}}, 5$ $\mathrm{HT}_{2 \mathrm{~A}}$ and $5-\mathrm{HT}_{2 \mathrm{C}}$ receptors [78].

Previous research has demonstrated that behavioral responses are related to visceral responses, which is reflected by the reduction of urinary volume after riparin III treatment $[75,79]$ proving stress treatment reduces urinary incontinence.

On Fig. 4d, physiologic parameters such as water consumption $(24 \mathrm{~h})$, did not demonstrate significant difference among periods (CP, AP and TP).

Spectral analyses of ${ }^{1} \mathrm{H}$ NMR from urine samples of $\mathrm{CP}, \mathrm{AP}$ and TP (Fig. 5) were submitted to multivariate data analysis, using PCA as statistical tool in order to visualize and detect slight differences among the distinct periods [80-82].

PCA analysis was used in order to verify differences among samples and classify them according to its ${ }^{1} \mathrm{H}$ NMR results, resulting in groups or clusters, reflecting on its distinct periods. According to the scores plot (Fig. 5a) it could be observed the formation of three distinct groups, classified as $\mathrm{CP}, \mathrm{AP}$ and $\mathrm{TP}$, which according to

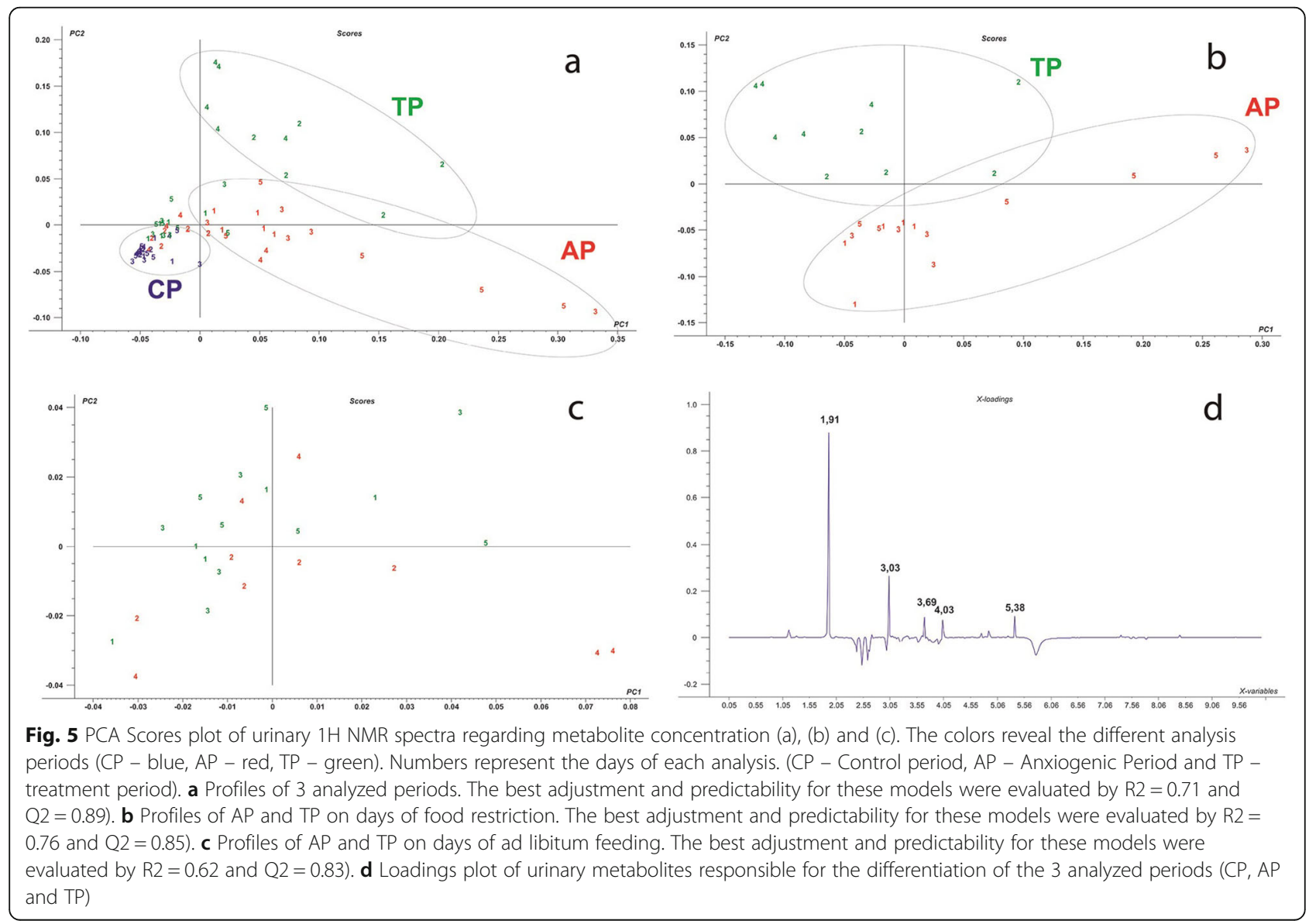


the loadings plot, (Fig. 5d) were differentiated by influence of five significant components [83]: cortisol $(\delta 1.91 \mathrm{~s})$, creatinine $(\delta 3.03 \mathrm{~s})$, riparin III $(\delta 3.69 \mathrm{~s})$, 5-hydroxy-L-triptophan $(\delta 4.03 \mathrm{dd})$ and allantoin $(\delta 5.38 \mathrm{~s})$, which were identified with the aid of TOCSY technique and confirmed by scientific literature [84-87].

The statistical analysis on Fig. 5b has also demonstrated that during food restriction, when analyzing only AP and $\mathrm{TP}$, the discrimination between groups was more evident, with a higher variance of $\mathrm{AP}$ along the $\mathrm{PC} 1$ dimension, and a $\mathrm{R} 2=0.76$. On the other hand, during ad libitum feeding the R2 correlation has diminished to 0.62 (Fig. 5c), indicating that feeding reduces stress.

It could be observed in the loadings plot (Fig. 6), variables or peaks responsible for the differentiation of each period or group. Regarding the loadings plot of control period $(\mathrm{CP})$, on Fig. 6a, it was demonstrated that the most important peaks responsible for its segregation were $\delta 2.53$ and $\delta 2.63$ for cyanocobalamin (vitamin B12), $\delta 1.91$ for cortisol, $\delta 5.38$ for allantoin and $\delta 5.78$ for urea, whereas the most influential peaks of the loadings plot concerning the anxiogenic period (AP) (Fig. 6b), were $\delta 1.91$ for cortisol and $\delta 3.03$ for creatinine. Moreover, in relation to the loadings plot of treatment period (Fig. 6c), it has demonstrated that the most influential peaks towards this particular group were $\delta 3.69$ for riparin III, $\delta 1.91$ for cortisol, $\delta 3.03$ for creatinine, $\delta 5.38$ for allantoin, $\delta 4.03$ for tryptophan and $\delta$ 5.78 for urea.
The metabolic profile of control period (Fig. 6a) is basically defined by metabolites from food constituents, among which, the peaks $\delta 2.53$ and $\delta 2.63$ from cyanocobalamin were one of the most important components from the ration provided, rich in B-complex vitamins. The presence of the cortisol peak is suggestive due to the permanence of the animals in a cage, with no physical activity during the whole experiment [1]; regarding the peaks of allantoin $(\delta 5.38)$ and urea $(\delta 5.78)$, it would be due to the expected physiology of rodents, catabolizing nitrogenized products. The anxiogenic period (Fig. $6 \mathrm{~b})$ was characterized by the presence of cortisol $(\delta 1.91)$ and creatinine ( $\delta 3.03$ ), which might be related to physical effort, caused by forced swimming, besides food restriction [88-90], indicating that these factors would be related to significant weight loss presented on Fig. 4b, once bioterium animals are sedentary, therefore the presence of these metabolites were not significantly important on EPM (Fig. 2) or OF tests (Fig. 3a). Regarding TP profile, the cortisol peak $(\delta 1.91)$ still had influence over this period, demonstrating that anxiogenic factors have remained, corroborating with Fig. 2 and Fig. 3a. The presence of creatinine $(\delta 3.03)$ and allantoin $(\delta 5.38)$ have indicated high catabolism of proteins, due to food restriction, however, the presence of the peak related to riparin III ( $\delta 3.69)$ was a very important parameter for this group, reflecting on the animal behavior of TP demonstrated by Fig. 3b, with the strong reduction of rearing and grooming (Fig. 3d) when compared to AP.

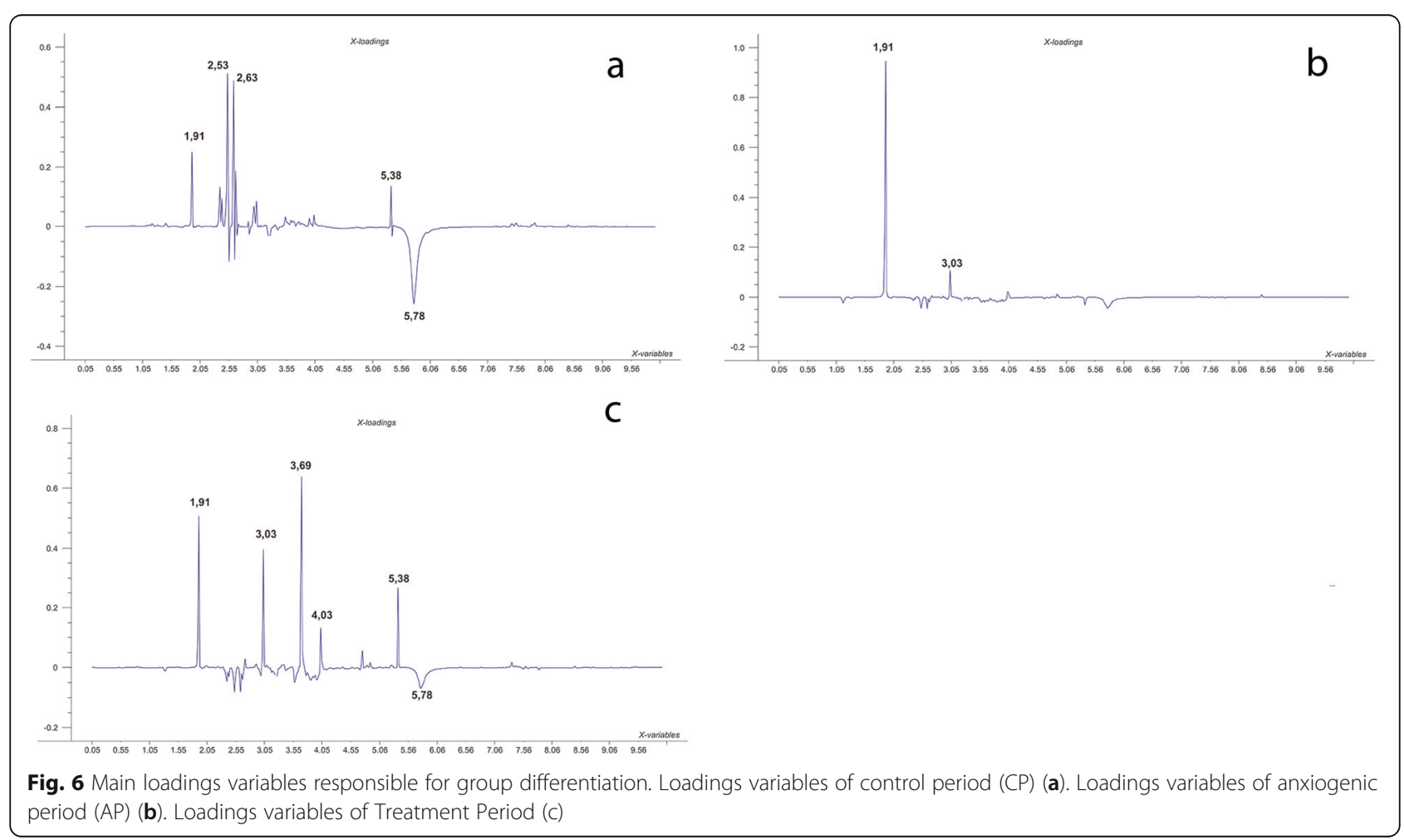


Furthermore, the observation of no significant difference between TP and CP regarding these two specific behaviors has reinforced its anxiolytic-like effect $[62,66,91]$.

The significant influence of tryptophan peak $(\delta 4.03)$ on TP (Fig. 6c) has suggested a deviation on metabolic path towards biosynthesis and/or storage of serotonin, once tryptophan is one of serotonin's precursor [92]. ANOVA one-way analysis, applying Bonferroni post-test upon the tryptophan areas of urine samples (Fig. 8b) has demonstrated significant difference between $\mathrm{CP}$ and $\mathrm{AP}$ periods, as well as between $\mathrm{CP}$ and $\mathrm{TP}$, but did not present significant difference between AP and TP. The peak $\delta 4.03$ was predominantly detected on animals from the TP group, indicating that those animals were under anxiolytic-like effect [57]. However it was also detected on treated animals, a peak related to riparin III ( $\delta$ $3.69)$ and a decrease related to cortisol $(\delta 1.91)$, indicating an antagonistic effect, or a reduction of cortisol levels due to riparin treatment, consequently inhibiting the anxiogenic induction.

Regarding the urea peak $(\delta 5.78)$ on Fig. 6 , it has presented a significant decrease on $\mathrm{CP}$, when correlated to AP and TP, but it was not observed a significant difference between AP and TP, which would be due to physiological needs of the animals in order to obtain energy [93], once they went through physical effort and food restriction, corroborating with creatinine peaks at $\delta$ 3.03, observed on Fig. 7a, which has increased
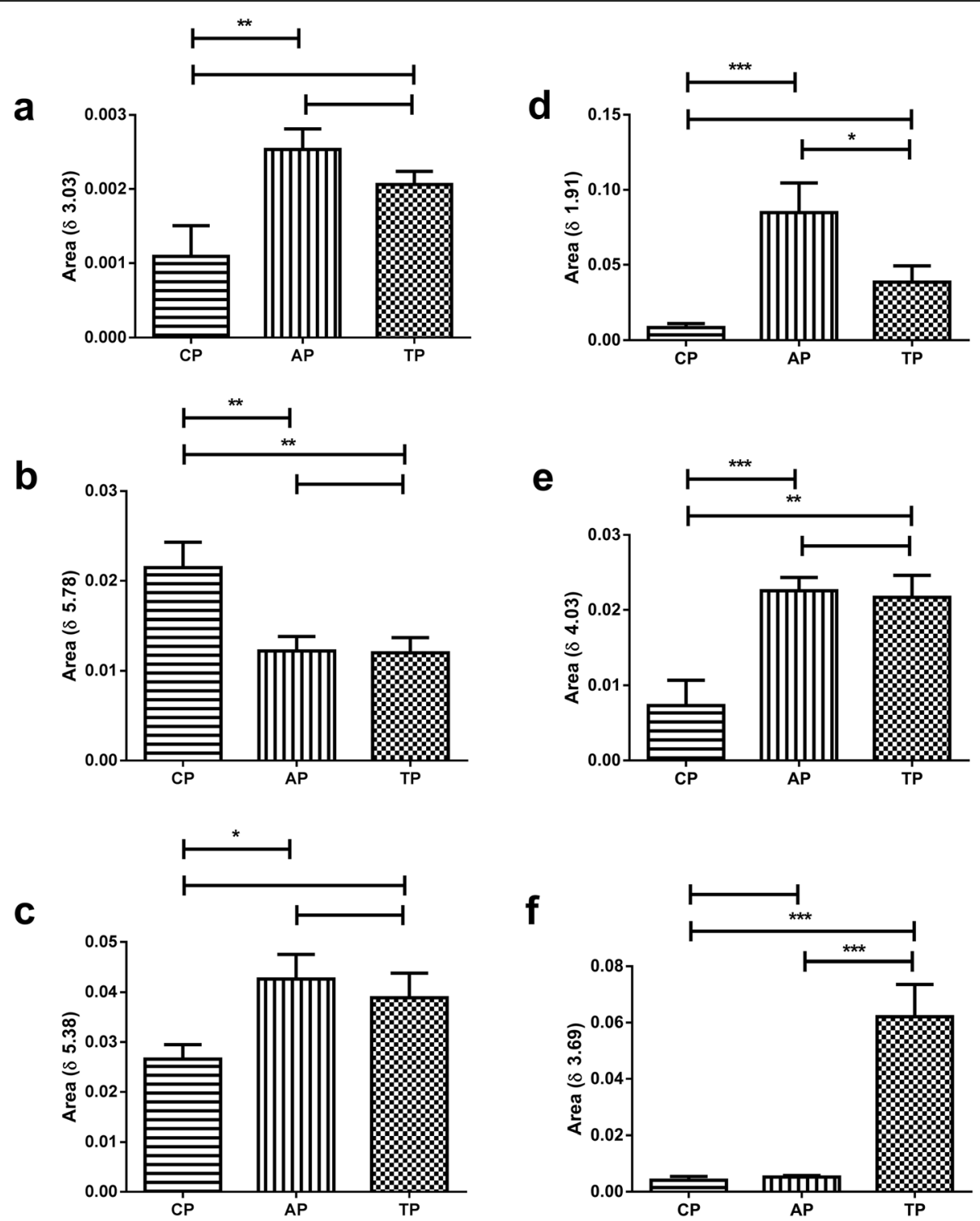

Fig. 7 Creatinine (a), Urea (b), Allantoin (c), Cortisol (d), Tryptophan (e) and Riparin peak (f) after physical effort and food restriction. CP: Control Period. AP: Anxiogenic Period. TP: Treatment Period. $p<0.05\left(^{*}\right) \cdot p<0.001\left(^{(* *}\right) \cdot p<0.0001{ }^{(* * *)}$ 
significantly on AP when compared to CP. The energetic needs were supplied by catabolism provided from muscular tissue [94]. The lack of significant difference between $\mathrm{CP}$ and TP, as well as between AP and TP (Fig. 7a), have suggested that during TP, there was a decrease concerning muscular stress, but no difference was detected on the previous period (AP) [95].

The Fig. $7 \mathrm{~d}$ and $\mathrm{f}$ have indicated an antagonistic effect, correlating cortisol $(\delta$ 1.91) and riparin III ( $\delta$ 3.69), which were also supported by behavioral studies (Fig. 3 $\mathrm{b}$ and $\mathrm{d})$. According to statistical analysis, it was observed a significant increase of riparin III (Fig. 7f) when comparing $\mathrm{CP}$ to $\mathrm{TP}$, and $\mathrm{AP}$ to $\mathrm{TP}$, besides, it was also observed a significant reduction of cortisol (Fig. 7d) when correlating AP to TP and no significant difference between $\mathrm{CP}$ and TP, demonstrating that the increase of riparin III has reduced the cortisol levels; consequently, the behavioral effects caused by cortisol (Fig. 3b and d) have diminished significantly due to the presence of riparin III, promoting anxiolytic-like effect [96, 97].

On Fig. 8 it could be highlighted the increasing area of peak $\delta 3.69$ from day 11 to 15 , corresponding to TP, however, on days 13 and 15, it was observed smaller areas, closer to day 11 . The animals went through food restriction on alternate days, from day 5 to 15 , with no ration at odd days. Riparin III is strongly bonded to albumin, and pre-albumin, considered by previous studies an indicative parameter of chronic innutrition [98], and acute innutrition respectively [99], along with high levels of creatinine and allantoin (Fig. 7 a and c) on AP and TP periods. Therefore, suggesting that on odd days, during AP and TP periods, the animals suffered of acute innutrition aggravated by forced swimming. It was also observed that on days 12 and 14, peak area at $\delta 3.69$ has increased to an average value of $0.0793 \pm 0.0175$ (Mean \pm SEM) and $0.1558 \pm 0.0141$ (Mean \pm SEM) respectively. Pre-albumin has a half-life of approximately $48 \mathrm{~h}[100$, 101] the average value of the peak area at $\delta 3.69$ has augmented 1.96 times when comparing day 12 and 14, however, on days $13(0.0289 \pm 0.0109)$ and $15(0.0282 \pm$ $0.0055)$, these values came closer to day $11(0.0180 \pm 0$, 0031). If on odd days, the concentration of pre-albumin drops due to the increase of catabolism caused by food restriction and physical effort, considering that its halflife is of $48 \mathrm{~h}$ and that on even days the anabolism increases due to food availability, consequently riparin III ( $\delta 3.69)$ has a half-life up to $12 \mathrm{~h}$, and the minor values at days 13 and 15 would be also due to the bond of riparin III with pre-albumin.

Previous research have demonstrated anxiolytic and antidepressant-like effect of riparin III in high doses by intraperitoneal administration [102]. In this work, the anxiolytic-like effect has been demonstrated at a lower dose by intravenous administration supported by metabolic profiling and behavioral tests. Moreover, it has been speculated that, due to its anxiolytic-like effect, riparin III in a $5 \mathrm{mg} \cdot \mathrm{kg}^{-1}$ dose acts on serotoninergic neurons [96] promoting a behavior controlled by amygdala [103], once previous studies have already indicated the role of amygdala on anxiety, specially its central core [57]. ${ }^{1} \mathrm{H}$ NMR data of urine samples were statistically treated by principal component analysis in order to detect patterns among the distinct periods evaluated, as well as biomarkers responsible for its distinction [104]. Cortisol, biomarker related to physiological stress, poorly indicates the psychological state [105], however it was supported by not only behavioral tests such as OF and EPM, but physiologic parameters analyses, that the reduction of cortisol by riparin III was related to anxiety reduction probably through activation of $5-\mathrm{HT}_{2 \mathrm{~A}}$ receptors [75]. Previous study has demonstrated that behavioral responses are related to visceral responses [75], in this context, the reduction of urinary volume after riparin III treatment [79] was also observed, corroborating with the cortisol level reduction, proving that stress treatment reduces urinary incontinence.

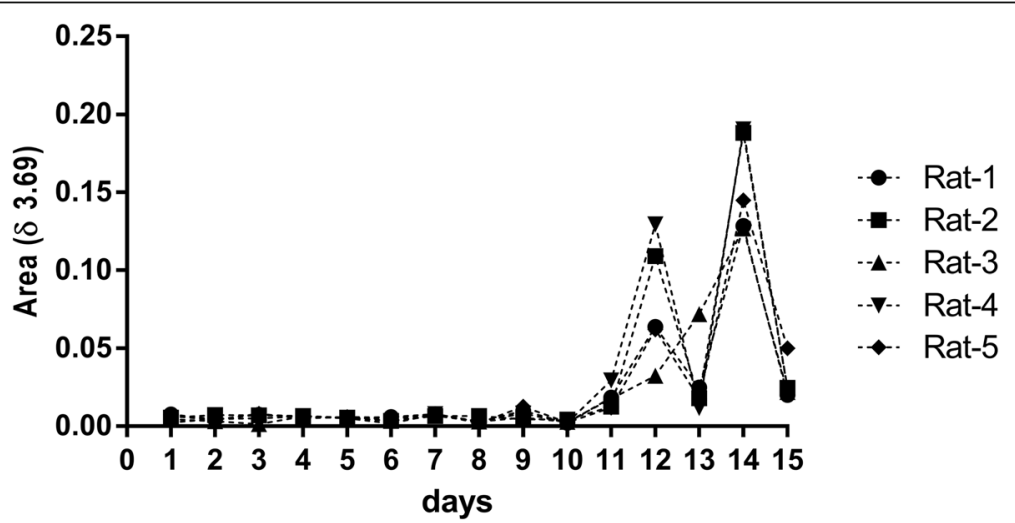

Fig. 8 Riparin III peaks on urine samples between days 11 and 15. The x-axis represents the days of the analyses. Days 0 to 4: Control Period (CP), days 5 to 10: Anxiogenic Period (AP) and days 11 to 15: Treatment Period (TP) 


\section{Conclusion}

Anxiolytic-like effect of riparin III has been demonstrated by behavioral tests such as open field and elevated plus-maze tests. The results were obtained at a lower dose by intravenous administration to Wistar rats. Moreover, it was not observed any hypnotic or sedative effect towards the animals whatsoever, ergo, preserving the vigilant state. These results were also supported by metabolic profiling from urine samples, obtained by the combination of ${ }^{1} \mathrm{H}$ NMR analysis and statistical treatment of its data by principal component analysis, which could detect cortisol, creatinine, allantoin and tryptophan as biomarkers. Therefore, urinary metabolic profiling by ${ }^{1} \mathrm{H}$ NMR spectroscopy combined with multivariate data analysis have demonstrated to be an important diagnostic tool to prove the anxiolytic-like effect of riparin III in a more efficient and pragmatic way.

\section{Abbreviations}

OF: Open field; EPM: Elevated plus-maze; CP: Control period; AP: Anxiogenic period; TP: Treatment period; TSP: 3-Trimethylsilil propionic acid;

PCA: Principal component analysis

\section{Acknowledgments}

We gratefully acknowledge Universidade Federal da Paraíba for covering publication costs.

\section{Declaration}

The experimental work described in this article was conducted in the Drug and Medicine Research Institute (IPeFarM), Universidade Federal da Paraíba, João Pessoa, Brazil, from February 2008 to May 2011. These studies are the result of our own investigations and have not been submitted in any other form to another journal.

\section{Authors' contributions}

S.G.S., J.F.T., S.J.C.G., R.N.A., J.M.B. and M.S.S designed and reviewed the research. S.G.S., A.M.F.O.G and I.F.G conducted the experiments. A.L.S and S.G.S wrote, reviewed and edited the paper. M.T.S performed the statistical data analysis. All authors read and approved the final manuscript.

\section{Funding}

This research was supported by the Coordenação de Aperfeiçoamento de Pessoal de Nível Superior - Brasil CAPES - Finance code 001, and Instituto Nacional de Ciência e Tecnologia (INCT/RENOFITO). The funding source had no role in study design, data collection and analysis, data interpretation and writing of the manuscript.

\section{Availability of data and materials}

The dataset generated during the present study is available upon reasonable request to the author (Prof. Marcelo Sobral).

\section{Ethics approval and consent to participate}

The whole experiment was approved by the ethics committee in animal research (ECAR), from Universidade Federal da Paraíba, João Pessoa/Paraíba, Brazil, under protocol $n^{\circ}$ 0107/08. The protocols are in agreement with the guidelines of the National Institute of Health (NIH Publication, Health Research Extension Act of 1985 Public Law 99-158, November 20, 1985 "Animals in Research") regarding animal care in laboratory.

\section{Consent for publication}

Not applicable.

\section{Competing interests}

The authors declare that they have no competing interests.

\section{Author details}

Instituto de Pesquisa de Fármacos e Medicamentos - IPeFarM, Universidade Federal da Paraíba, João Pessoa, PB 58051-900, Brazil. 'Departamento de Tecnologia de Alimentos, Centro de Tecnologia e Desenvolvimento Regional, Universidade Federal da Paraíba, João Pessoa, PB 58051-900, Brazil.

Received: 12 September 2019 Accepted: 27 April 2020

Published online: 16 May 2020

\section{References}

1. Miladi-Gorji H, Rashidy-Pour A, Fathollahi Y. Anxiety profile in morphinedependent and withdrawn rats: effect of voluntary exercise. Physiol Behav. 2012;105(2):195-202.

2. von Glischinski M, von Brachel R, Hirschfeld G. How depressed is "depressed"? A systematic review and diagnostic meta-analysis of optimal cut points for the Beck depression inventory revised (BDI-II). Qual Life Res. 2019;28(5):1111-8.

3. Li SYH, Bressington D. The effects of mindfulness-based stress reduction on depression, anxiety, and stress in older adults: a systematic review and meta-analysis. Int J Ment Health Nurs. 2019;28(3):635-56.

4. Kalandakanond-Thongsong S, Daendee S, Srikiatkhachorn A. Effect of the acute and chronic estrogen on anxiety in the elevated T-maze. Physiol Behav. 2012;105(2):357-63.

5. Pérez-Ortega G, Guevara-Fefer P, Chávez M, Herrera J, Martínez A, Martínez $A L$, et al. Sedative and anxiolytic efficacy of Tilia americana var. mexicana inflorescences used traditionally by communities of state of Michoacan, Mexico. J Ethnopharmacol. 2008;116(3):461-8.

6. Hennebelle T, Sahpaz S, Bailleul F. Plantes sédatives : évaluation pharmacologique et clinique. Médecine du Sommeil. 2007;4(13):4-14

7. Wijeweera P, Arnason JT, Koszycki D, Merali Z. Evaluation of anxiolytic properties of Gotukola - (Centella asiatica) extracts and asiaticoside in rat behavioral models. Phytomedicine. 2006;13(9-10):668-76.

8. Rabbani M, Sajjadi SE, Jafarian A, Vaseghi G. Anxiolytic effects of Salvia reuterana Boiss. On the elevated plus-maze model of anxiety in mice. J Ethnopharmacol. 2005;101(1-3):100-3.

9. Rock EM, Limebeer $C L$, Petrie GN, Williams LA, Mechoulam R, Parker LA. Effect of prior foot shock stress and $\Delta$ 9-tetrahydrocannabinol, cannabidiolic acid, and cannabidiol on anxiety-like responding in the light-dark emergence test in rats. Psychopharmacology. 2017;234(14):2207-17.

10. Liu T, Ma Y, Zhang R, Zhong H, Wang L, Zhao J, et al. Resveratrol ameliorates estrogen deficiency-induced depression- and anxiety-like behaviors and hippocampal inflammation in mice. Psychopharmacology. 2019;236(4):1385-99.

11. Faustino TT, RBd A. Andreatini R. Plantas medicinais no tratamento do transtorno de ansiedade generalizada: uma revisão dos estudos clínicos controlados. Rev Bras Psiquiatr. 2010;32:429-36.

12. Barbosa-Filho JM, Yoshida M, Gottlieb O. The tyramines of Aniba riparia: transformation into models of natural products. Revista Latinoamericana de Química. 1990;21(1):5-7.

13. Barbosa-Filho JM, Yoshida M, R. Gottlieb O, RdCSBC B, Giesbrecht AM, MCM $Y$. Benzoyl esters and amides, styrylpyrones and neolignans from the fruits of Aniba riparia. Phytochemistry. 1987;26(9):2615-7.

14. Melo CTV, Monteiro AP, Leite CP. Ara, uacute, jo FLOd, et al. anxiolytic-like effects of (O-methyl)-N-2,6-dihydroxybenzoyl-tyramine (Riparin III) from Aniba riparia (NEES) MEZ (Lauraceae) in mice. Biol Pharm Bull. 2006;29(3): $451-4$.

15. Melo CTV, Monteiro AP, Leite CP, Araújo FLO, Lima VTM, Barbosa-Filho JM, et al. Anxiolytic-like effects of (O-methyl)-N-2,6-dihydroxybenzoyl-tyramine (Riparin III) from Aniba riparia (NEES) MEZ (Lauraceae) in mice. Biol Pharm Bull. 2006;29(3):451-4.

16. Araújo FLO, Melo CTV, Rocha NFM, Moura BA, Leite CP, Amaral JF, et al. Antinociceptive effects of (O-methyl)-N-benzoyl tyramine (riparin I) from Aniba riparia (Nees) Mez (Lauraceae) in mice. Naunyn Schmiedeberg's Arch Pharmacol. 2009;380(4):337-44.

17. Rios MY, Olivo HF. Chapter 3 - Natural and Synthetic Alkamides: Applications in Pain Therapy. In: Atta Ur R, editor. Studies in Natural Products Chemistry, vol. 43. Great Britain: Elsevier; 2014. p. 79-121.

18. Sousa FCF, Monteiro AP, Melo CTV, Oliveira GR, Vasconcelos SMM, Fonteles MMF, et al. Antianxiety effects of riparin I from Aniba riparia (Nees) Mez (Lauraceae) in mice. Phytother Res. 2005;19(12):1005-8. 
19. Teixeira CPL, Melo CTV, Araújo FLO, Carvalho AMR, Silva MIG, Barbosa-Filho $J M$, et al. Antidepressant-like effect of riparin II from Aniba riparia in mice: evidence for the involvement of the monoaminergic system. Fundam Clin Pharmacol. 2013;27(2):129-37.

20. EJFd A, Rezende-Júnior LM, LKF L, MPd S-J, Silva OA, BPd SN, et al. Pathophysiological investigations, anxiolytic effects and interaction of a semisynthetic riparin with benzodiazepine receptors. Biomed Pharmacother. 2018;103:973-81.

21. Kim IY, Jung J, Jang M, Ahn YG, Shin JH, Choi JW, et al. 1H NMR-based metabolomic study on resistance to diet-induced obesity in AHNAK knockout mice. Biochem Biophys Res Commun. 2010;403(3-4):428-34.

22. Saude EJ, Skappak CD, Regush S, Cook K, Ben-Zvi A, Becker A, et al. Metabolomic profiling of asthma: Diagnostic utility of urine nuclear magnetic resonance spectroscopy. J Allergy Clin Immunol. 2011;127(3):75764.e6

23. Moaddel R, Shardell M, Khadeer M, Lovett J, Kadriu B, Ravichandran S, et al. Plasma metabolomic profiling of a ketamine and placebo crossover trial of major depressive disorder and healthy control subjects. Psychopharmacology. 2018;235(10):3017-30.

24. Zhu L, Liang Z-T, Yi T, Ma Y, Zhao Z-Z, Guo B-L, et al. Comparison of chemical profiles between the root and aerial parts from three Bupleurum species based on a UHPLC-QTOF-MS metabolomics approach. BMC Complement Altern Med. 2017;17(1):305.

25. Nagana Gowda GA, Raftery D. Whole blood metabolomics by 1 H NMR spectroscopy provides a new opportunity to evaluate coenzymes and antioxidants. Anal Chem. 2017:89(8):4620-7.

26. Al-Zuaidy MH, Mumtaz MW, Hamid AA, Ismail A, Mohamed S, Razis AFA. Biochemical characterization and 1 H NMR based metabolomics revealed Melicope lunu-ankenda leaf extract a potent anti-diabetic agent in rats. BMC Complement Altern Med. 2017;17(1):359.

27. Lee SY, Mediani A, Ismail IS, Maulidiani AF. Antioxidants and a-glucosidase inhibitors from Neptunia oleracea fractions using $1 \mathrm{H}$ NMR-based metabolomics approach and UHPLC-MS/MS analysis. BMC Complement Altern Med. 2019;19(1):7.

28. Jankevics A, Liepinsh E, Liepinsh E, Vilskersts R, Grinberga S, Pugovics O, et al. Metabolomic studies of experimental diabetic urine samples by $1 \mathrm{H}$ NMR spectroscopy and LC/MS method. Chemom Intell Lab Syst. 2009;97(1): $11-7$.

29. Gowda GAN, Zhang S, Gu H, Asiago V, Shanaiah N, Raftery D. Metabolomics-based methods for early disease diagnostics. Expert Rev Mol Diagn. 2008;8(5):617-33.

30. Wold S, Esbensen K, Geladi P. Principal Component Analisis. Chemom Intell Lab Syst. 1987:2:37-52

31. Yang Q, Xu L, Tang L-J, Yang J-T, Wu B-Q, Chen N, et al. Simultaneous detection of multiple inherited metabolic diseases using GC-MS urinary metabolomics by chemometrics multi-class classification strategies. Talanta. 2018:186:489-96.

32. Wojtowicz W, Zabek A, Deja S, Dawiskiba T, Pawelka D, Glod M, et al. Serum and urine $1 \mathrm{H}$ NMR-based metabolomics in the diagnosis of selected thyroid diseases. Sci Rep. 2017;7(1):9108.

33. Azam AA, Pariyani R, Ismail IS, Ismail A, Khatib A, Abas F, et al. Urinary metabolomics study on the protective role of Orthosiphon stamineus in Streptozotocin induced diabetes mellitus in rats via $1 \mathrm{H}$ NMR spectroscopy. BMC Complement Altern Med. 2017;17(1):278.

34. Barbosa-Filho JM. Silva ECd, Bhattacharyya J. synthesis of several new phenylethylamides of substituited benzoic acids. Quim Nova. 1990;13(4): 332-4.

35. Silvestre JS, Fernández AG, Palacios JM. Effects of rolipram on the elevated plus-maze test in rats: a preliminary study. J Psychopharmacol. 1999;13(3): 274-7.

36. Aikey JL, Nyby JG, Anmuth DM, James PJ. Testosterone rapidly reduces anxiety in male house mice (Mus musculus). Horm Behav. 2002;42(4):448-60.

37. Broadhurst PL. Determinants of emotionality in the rat. Br J Psychol. 1958; 49(1):12-20.

38. Broadhurst PL. Determinants of emotionality in the rat: II. Strain differences. J Comp Physiol Psychol. 1958;51(1):55-9.

39. Natelson $\mathrm{BH}$, Janocko L, Jacoby JH. An interaction between dietary tryptophan and stress in exacerbating gastric disease. Physiol Behav. 1981; 26(2):197-200

40. Schnorr CE, Morrone MDS, Weber MH, Lorenzi R, Behr GA, Moreira JCF. The effects of vitamin a supplementation to rats during gestation and lactation upon redox parameters: increased oxidative stress and redox modulation in mothers and their offspring. Food Chem Toxicol. 2011;49(10):2645-54.

41. Khasar SG, Dina OA, Green PG, Levine JD. Sound stress-induced Long-term enhancement of mechanical Hyperalgesia in rats is maintained by Sympathoadrenal Catecholamines. J Pain. 2009;10(10):1073-7.

42. Dina OA, Levine JD, Green PG. Enhanced cytokine-induced mechanical hyperalgesia in skeletal muscle produced by a novel mechanism in rats exposed to unpredictable sound stress. Eur J Pain. 2011;15(8):796-800.

43. de Paula SV, Vicente MA, Biojone C, Zangrossi H Jr, Guimarães FS, Joca SRL. Distinct behavioral consequences of stress models of depression in the elevated T-maze. Behav Brain Res. 2011;225(2):590-5

44. Silva FC, Presgrave OAF. Manual de Utilização de Animais/FIOCRUZ. Rio de Janeiro: Fundação Oswaldo Cruz - FIOCRUZ; 2008.

45. Damy SB, Camargo RS. Chammas R, Figueiredo LFPd. Aspectos fundamentais da experimentação animal - aplicações em cirurgia experimental. Revista da Associação Médica Brasileira. 2010;56:103-11.

46. Schmitt U, Hiemke C. Combination of open field and elevated plus-maze: a suitable test battery to assess strain as well as treatment differences in rat behavior. Prog Neuro-Psychopharmacol Biol Psychiatry. 1998;22(7):1197-215.

47. Lister RG. The use of a plus-maze to measure anxiety in the mouse. Psychopharmacology. 1987;92(2):180-5.

48. Bradley BF, Starkey NJ, Brown SL, Lea RW. Anxiolytic effects of Lavandula angustifolia odour on the Mongolian gerbil elevated plus maze. J Ethnopharmacol. 2007;111(3):517-25.

49. de Almeida RN, Motta SC, de Brito FC, Catallani B, Leite JR. Anxiolytic-like effects of rose oil inhalation on the elevated plus-maze test in rats. Pharmacol Biochem Behav. 2004;77(2):361-4.

50. Hrubá L, Schutová B, Šlamberová R. Sex differences in anxiety-like behavior and locomotor activity following prenatal and postnatal methamphetamine exposure in adult rats. Physiol Behav. 2012;105(2):364-70.

51. Sun B, Li L, Wu S, Zhang Q, Li H, Chen H, et al. Metabolomic analysis of biofluids from rats treated with Aconitum alkaloids using nuclear magnetic resonance and gas chromatography/time-of-flight mass spectrometry. Anal Biochem. 2009:395(2):125-33.

52. Kim K-B, Um SY, Chung MW, Jung SC, Oh JS, Kim SH, et al. Toxicometabolomics approach to urinary biomarkers for mercuric chloride ( $\mathrm{HgCl} 2)$-induced nephrotoxicity using proton nuclear magnetic resonance (1H NMR) in rats. Toxicol Appl Pharmacol. 2010;249(2):114-26.

53. Sheedy JR, Ebeling PR, Gooley PR, McConville MJ. A sample preparation protocol for $1 \mathrm{H}$ nuclear magnetic resonance studies of water-soluble metabolites in blood and urine. Anal Biochem. 2010;398(2):263-5.

54. Pellow S, Chopin P, File SE, Briley M. Validation of open : closed arm entries in an elevated plus-maze as a measure of anxiety in the rat. J Neurosci Methods. 1985;14(3):149-67.

55. McGuire J, Herman JP, Horn PS, Sallee FR, Sah R. Enhanced fear recall and emotional arousal in rats recovering from chronic variable stress. Physiol Behav. 2010;101(4):474-82

56. Morrow BA, George TP, Roth RH. Noradrenergic a-2 agonists have anxiolytic-like actions on stress-related behavior and mesoprefrontal dopamine biochemistry. Brain Res. 2004;1027(1-2):173-8.

57. Davis M. The role of the amygdala in fear and anxiety. Annu Rev Neurosci. 1992;15(1):353-75.

58. Calvez J, Fromentin G, Nadkarni N, Darcel N, Even P, Tomé D, et al, Inhibition of food intake induced by acute stress in rats is due to satiation effects. Physiol Behav. 2011;104(5):675-83.

59. Karim N, Irshad S, Khan I, Mohammad A, Anis I, Shah MR, et al. GABAA receptor modulation and neuropharmacological activities of viscosine isolated from Dodonaea viscosa (Linn). Pharmacol Biochem Behav. 2015;136:64-72.

60. Khan AW, Khan A-U, Ahmed T. anticonvulsant, anxiolytic, and sedative activities of Verbena officinalis. Front Pharmacol. 2016;7:499.

61. Sandoval-Herrera V, Trujillo-Ferrara JG, Miranda-Páez A, De La Cruz F, Zamudio SR. Corticosterone microinjected into nucleus pontis oralis increases tonic immobility in rats. Horm Behav. 2011;60(4):448-56.

62. Cannizzaro C, Plescia F, Gagliano M, Cannizzaro G, Mantia G, La Barbera M, et al. Perinatal exposure to 5-metoxytryptamine, behavioural-stress reactivity and functional response of 5-HT1A receptors in the adolescent rat. Behav Brain Res. 2008;186(1):98-106.

63. Corley MJ, Caruso MJ, Takahashi LK. Stress-induced enhancement of fear conditioning and sensitization facilitates extinction-resistant and habituation-resistant fear behaviors in a novel animal model of posttraumatic stress disorder. Physiol Behav. 2012;105(2):408-16. 
64. Ferré $P$, Fernández-Teruel $A$, Escorihuela RM, Driscoll $P$, Corda MG, Giorgi $O$, et al. Behavior of the Roman/Nerh high- and low-avoidance rat lines in anxiety tests: relationship with defecation and self-grooming. Physiol Behav. 1995;58(6):1209-13.

65. Hall CS. Emotional behavior in the rat. I. Defecation and urination as measures of individual differences in emotionality. J Comp Psychol. 1934; 18(3):385-403.

66. Febo M, Felix-Ortiz AC, Johnson TR. Inactivation or inhibition of neuronal activity in the medial prefrontal cortex largely reduces pup retrieval and grouping in maternal rats. Brain Res 2010;1325(0):77-88.

67. Rok-Bujko P, Krząścik P, Szyndler J, Kostowski W, Stefański R. The influence of neonatal serotonin depletion on emotional and exploratory behaviours in rats. Behav Brain Res. 2012;226(1):87-95.

68. Salim S, Sarraj N, Taneja M, Saha K, Tejada-Simon MV, Chugh G. Moderate treadmill exercise prevents oxidative stress-induced anxiety-like behavior in rats. Behav Brain Res. 2010;208(2):545-52.

69. Douglas AJ, Johnstone LE, Leng G. Neuroendocrine mechanisms of change in food intake during pregnancy: a potential role for brain oxytocin. Physiol Behav. 2007:91(4):352-65

70. Neuhäuser-Berthold M, Wirth S, Hellmann U, Bässler KH. Utilisation of Nacetyl-L-glutamine during long-term parenteral nutrition in growing rats: significance of glutamine for weight and nitrogen balance. Clin Nutr. 1988, 7(3):145-50

71. Holecek M, Kovarik M. Alterations in protein metabolism and amino acid concentrations in rats fed by a high-protein (casein-enriched) diet - effect of starvation. Food Chem Toxicol. 2011;49(12):3336-42.

72. Currie PJ, Khelemsky R, Rigsbee EM, Dono LM, Coiro CD, Chapman CD, et al. Ghrelin is an orexigenic peptide and elicits anxiety-like behaviors following administration into discrete regions of the hypothalamus. Behav Brain Res. 2012;226(1):96-105.

73. Ullrich PM, Lutgendorf SK, Kreder KJ. Physiologic reactivity to a laboratory stress task among men with benign prostatic hyperplasia. Urology. 2007; 70(3):487-91.

74. Sugaya K, Nishijima S, Miyazato M, Ogawa Y. Central nervous control of micturition and urine storage. J Smooth Muscle Res. 2005;41(3):117-32.

75. Kadekawa K, Nishijima S, Sugaya K, Miyazato M, Saito S. Mechanisms by which the serotonergic system inhibits micturition in rats. Life Sci. 2009; 85(15-16):592-6.

76. Guy G. 5-Hydroxytryptamine-interacting drugs in animal models of anxiety disorders: more than 30 years of research. Pharmacol Ther. 1995;65(3):319-95.

77. Graeff FG, Viana MB, Mora PO. Dual role of 5-HT in defense and anxiety. Neurosci Biobehav Rev. 1997;21(6):791-9.

78. Boisvert JP, Boschuetz TJ, Resch JM, Mueller CR, Choi S. Serotonin mediated changes in corticotropin releasing factor mRNA expression and feeding behavior isolated to the hypothalamic paraventricular nuclei. Neurosci Lett. 2011;498(3):213-7.

79. Jung SY, Fraser MO, Ozawa H, Yokoyama O, Yoshiyama M, De Groat WC, et al. Urethral afferent nerve activity affects the micturition reflex; implication for the relationship between stress incontinence and detrusor instability. J Urol. 1999;162(1):204-12.

80. Zhou Y, Lu L, Li Z, Gao X, Tian J, Zhang L, et al. Antidepressant-like effects of the fractions of Xiaoyaosan on rat model of chronic unpredictable mild stress. J Ethnopharmacol. 2011;137(1):236-44.

81. Kang S-M, Park J-C, Shin M-J, Lee H, Oh J, Ryu DH, et al. $1 \mathrm{H}$ nuclear magnetic resonance based metabolic urinary profiling of patients with ischemic heart failure. Clin Biochem. 2011;44(4):293-9.

82. Ryan D, Robards K, Prenzler PD, Kendall M. Recent and potential developments in the analysis of urine: a review. Anal Chim Acta. 2011; 684(1-2):17-29.

83. Jansen JJ, Hoefsloot HCJ, van der Greef J, Timmerman ME, Smilde AK. Multilevel component analysis of time-resolved metabolic fingerprinting data. Anal Chim Acta. 2005;530(2):173-83.

84. Jung J, Park M, Park HJ, Shim SB, Cho YH, Kim J, et al. 1H NMR-based metabolic profiling of naproxen-induced toxicity in rats. Toxicol Lett. 2011; 200(1-2):1-7.

85. Ebbels TMD, Holmes $E$, Lindon JC, Nicholson JK. Evaluation of metabolic variation in normal rat strains from a statistical analysis of $1 \mathrm{H}$ NMR spectra of urine. J Pharm Biomed Anal. 2004;36(4):823-33.

86. Constantinou MA, Papakonstantinou E, Spraul M, Sevastiadou S, Costalos C, Koupparis MA, et al. 1H NMR-based metabonomics for the diagnosis of inborn errors of metabolism in urine. Anal Chim Acta. 2005;542(2):169-77.
87. Wang H-P, Liang Y-J, Zhang Q, Long D-X, Li W, Li L, et al. Changes in metabolic profiles of urine from rats following chronic exposure to anticholinesterase pesticides. Pestic Biochem Physiol. 2011;101(3):232-9.

88. Ernest LA. Physiological correlates of the forced swim test in rats. Physiol Behav. 1993;54(2):309-17.

89. Pinheiro-Mulder A, Aguila MB, Bregman R, Alberto M-d-L C. Exercise counters diet-induced obesity, proteinuria, and structural kidney alterations in rat. Pathol Res Pract. 2010;206(3):168-73.

90. Yankelevitch-Yahav R, Franko M, Huly A, Doron R. The forced swim test as a model of depressive-like behavior. J Vis Exp. 2015;97:52587.

91. Muehlmann AM, Wilkinson JA, Devine DP. Individual differences in vulnerability for self-injurious behavior: studies using an animal model. Behav Brain Res. 2011;217(1):148-54.

92. Baumann MH, Williams Z, Zolkowska D, Rothman RB. Serotonin (5-HT) precursor loading with 5-hydroxy-l-tryptophan (5-HTP) reduces locomotor activation produced by (+)-amphetamine in the rat. Drug Alcohol Depend. 2011;114(2-3):147-52.

93. Guarnieri G, Barazzoni R. Fighting protein-energy wasting in chronic kidney disease: a challenge of complexity. J Ren Nutr. 2011;21(1):2-6.

94. Andersen TB, Jødal L, Boegsted M, Erlandsen EJ, Morsing A, Frøkiær J, et al. GFR prediction from Cystatin C and Creatinine in children: effect of including body cell mass. Am J Kidney Dis. 2012;59(1):50-7.

95. Rossi L, Tirapegui J. Implicações do sistema serotoninérgico no exercício físico. Arq Bras Endocrinol Metabol. 2004;48:227-33.

96. Miyata S, Shimoi T, Hirano S, Yamada N, Hata Y, Yoshikawa N, et al. Effects of serotonergic anxiolytics on the freezing behavior in the elevated openplatform test in mice. J Pharmacol Sci. 2007;105(3):272-8.

97. Borsini F, Podhorna J, Marazziti D. Do animal models of anxiety predict anxiolytic-like effects of antidepressants? Psychopharmacology. 2002;163(2): $121-41$.

98. Rubio-Ruiz ME, Díaz-Díaz E, Cárdenas-León M, Argüelles-Medina R, SánchezCanales P, Larrea-Gallo F, et al. Glycation does not modify bovine serum albumin (BSA)-induced reduction of rat aortic relaxation: the response to glycated and nonglycated BSA is lost in metabolic syndrome. Glycobiology. 2008;18(7):517-25.

99. Navab M, Smith JE, Goodman DS. Rat plasma prealbumin. Metabolic studies on effects of vitamin a status and on tissue distribution. J Biol Chem. 1977; 252(14):5107-14.

100. Saka B, Ozturk GB, Uzun S, Erten N, Genc S, Karan MA, et al. Nutritional risk in hospitalized patients: impact of nutritional status on serum prealbumin. Rev Nutr. 2011;24:89-98.

101. Beck FK, Rosenthal TC. Prealbumin: a marker for nutritional evaluation. Am Fam Physician. 2002;65(8):1575-83.

102. Sousa FCF, Melo CTV, Monteiro AP, Lima VTM, Gutierrez SJC, Pereira BA, et al. Antianxiety and antidepressant effects of riparin III from Aniba riparia (Nees) Mez (Lauraceae) in mice. Pharmacol Biochem Behav. 2004;78(1):27-33.

103. Fernandez SP, Gaspar P. Investigating anxiety and depressive-like phenotypes in genetic mouse models of serotonin depletion. Neuropharmacology. 2012;62(1):144-54.

104. Liu Y, Huang R, Liu L, Peng J, Xiao B, Yang J, et al. Metabonomics study of urine from Sprague-Dawley rats exposed to Huang-Yao-zi using $1 \mathrm{H}$ NMR spectroscopy. J Pharm Biomed Anal. 2010;52(1):136-41.

105. Folkedal O, Stien LH, Torgersen T, Oppedal F, Olsen RE, Fosseidengen JE, et al. Food anticipatory behaviour as an indicator of stress response and recovery in Atlantic salmon post-smolt after exposure to acute temperature fluctuation. Physiol Behav. 2012;105(2):350-6.

\section{Publisher's Note}

Springer Nature remains neutral with regard to jurisdictional claims in published maps and institutional affiliations. 